\title{
Resveratrol Production in Yeast Hosts: Current Status and Perspectives
}

\author{
Gehad G. Ibrahim ${ }^{1,2} \mathbb{D}$, Jinyong Yan ${ }^{1}, \mathrm{Li} \mathrm{Xu}{ }^{1}$, Min Yang ${ }^{1}$ and Yunjun Yan ${ }^{1, * \mathbb{C}}$ \\ 1 Key Laboratory of Molecular Biophysics of the Ministry of Education, College of Life Science and Technology, \\ Huazhong University of Science and Technology, Wuhan 430074, China; ggibrahim@zu.edu.eg (G.G.I.); \\ yjiny@126.com (J.Y.); xuli@mail.hust.edu.cn (L.X.); 2020010082@mail.hust.edu.cn (M.Y.) \\ 2 Department of Genetics, Faculty of Agriculture, Zagazig University, Zagazig 44511, Egypt \\ * Correspondence: yanyunjun@hust.edu.cn
}

check for updates

Citation: Ibrahim, G.G.; Yan, J.; Xu, L.; Yang, M.; Yan, Y. Resveratrol Production in Yeast Hosts: Current Status and Perspectives. Biomolecules 2021, 11, 830. https://doi.org/ 10.3390/biom 11060830

Academic Editor: Maria Stefania Sinicropi

Received: 28 April 2021

Accepted: 30 May 2021

Published: 2 June 2021

Publisher's Note: MDPI stays neutral with regard to jurisdictional claims in published maps and institutional affiliations.

Copyright: (C) 2021 by the authors Licensee MDPI, Basel, Switzerland. This article is an open access article distributed under the terms and conditions of the Creative Commons Attribution (CC BY) license (https:// creativecommons.org/licenses/by/ $4.0 /)$.

\begin{abstract}
Resveratrol is a plant secondary metabolite known for its therapeutic applications as an antioxidant, anti-cancer, anti-inflammatory, anti-aging, cardio-protective, and neuroprotective agent. Topical formulas of resveratrol are also used for skin disease management and in cosmetic industries. Due to its importance, high resveratrol production is urgently required. Since the last decade, intensive efforts have been devoted to obtaining resveratrol from microorganisms by pathway and metabolic engineering. Yeasts were proven to be excellent host candidates for resveratrol production. In addition to the similar intracellular compartments between yeasts and plants, yeasts exhibit the ability to express genes coding for plant-derived enzymes and to perform post-translational modification. Therefore, this review summarizes the attempts to use yeasts as a platform for resveratrol synthesis as the next promising route in producing high titers of resveratrol from genetically engineered strains.
\end{abstract}

Keywords: resveratrol; yeast hosts; pathway engineering; metabolic engineering

\section{Introduction}

Resveratrol (3,4', 5 -trihydroxystilbene) is a natural polyphenolic phytoalexin that belongs to the stilbenoids group of secondary metabolites [1-3]. Stilbenes are known for their ability to protect plants from UV light and the effect of chemical fertilizers [4], and for the defense of plants against biotic stresses such as bacterial, fungal, or nematode infections [3,5]. Resveratrol was first identified in 1940 as a constitutive compound of white hellebore roots (Veratrum grandiflorum) [6]. The richest source of resveratrol was found in Polygonum cuspidatum roots, the extract of which is widely used in traditional Chinese and Japanese medicine to treat human fungal diseases, such as gonococcal infection, suppurative dermatitis, tinea favosa and tinea pedis infections, hyperlipidemia, arteriosclerosis, and inflammations $[1,7]$. Thus far, resveratrol has been found in various plant species, such as grape berries [8], blueberries, cranberries (Vaccinium spp.) [9,10], blackberries, mulberries (Rubus and Morus spp.) [11,12], peanuts (Arachis hypogaea) [13], and jackfruit (Artocarpus heterophyllus) [11]. Naturally, there are two isomeric forms of resveratrol (Figure 1) but the trans isomer is the biologically active form [4]. However, under high $\mathrm{pH}$ values or UV-light exposure, resveratrol converts from the trans isoform into the cis isomer [14]. Both isomers exist as glucosides, and 3-O- $\beta$-D-resveratrol glucoside (piceid or polydatin) is the richest source of resveratrol in the glucoside form $[1,14,15]$.

Resveratrol was found to be the reason for the well-known French Paradox, assuming that, despite the high consumption of saturated fats, French people show lower coronary heart disease incidence than other communities. This phenomenon can be explained by the consumption of red wine, which is a source of resveratrol $[16,17]$.

Resveratrol has been widely studied in the past three decades $[18,19]$ due to the accumulated evidence of its therapeutic properties. Resveratrol exhibits biological activities as a 
cardioprotective [20], anti-cancer [21-24], and possible anti-inflammatory [25] agent. Additional clinical evidence points to resveratrol's role in cardiovascular disorder treatment [26], its impact on cell immunomodulation [27], and its role in lowering blood pressure [28]. Resveratrol has been suggested to have protective effects on neurodegenerative diseases, such as Alzheimer's and Parkinson's diseases [29-32]. Furthermore, resveratrol exhibits a positive role in treating periodontitis-related tissue defects and increased bone formation in mice morals [33].<smiles>Oc1ccc(/C=C\c2cc(O)cc(O)c2)cc1</smiles><smiles>Oc1ccc(/C=C/c2ccc(O)cc2)cc1</smiles>

Figure 1. Chemical structures of resveratrol: (a) cis-resveratrol isomer and (b) trans-resveratrol isomer.

In recent years, resveratrol's topical formulations have been used in cosmetic skincare products [34] and skin disease management. Topical formulations of resveratrol have been reported to be valuable in treating skin diseases, such as acne, eczema, exfoliation, and psoriasis [35,36], and as a potent whitening agent [1]. Resveratrol's antioxidant, antimicrobial, and antiviral effects provide skin protection from infections and ultravioletradiation-mediated oxidative stress (resulting in skin cancer and actinic keratosis) and show anti-aging properties [16,37]. Resveratrol was also found to accelerate skin wound healing [38].

Similar to glucosylated and methylated resveratrol derivatives, resveratrol oligomers present beneficial biological activities. Resveratrol-3-O-D-glycoside (piceid) shows antioxidant, anti-inflammatory, antitumor, hepatoprotective, and neuroprotective effects [39]. Many methylated derivatives, such as pterostilbene, trimethoxystilbene, and DMU212, possess more desirable pharmacokinetic properties than resveratrol and exhibit cardioprotective [40], anti-cancer [41-43], and neuroprotective activities [44,45]. Similarly, resveratrol oligomers such as pallidol [46,47], $\varepsilon$-viniferin [46,48-50], and labruscol [51] exhibit cytotoxic effects on cancer cell lines. Some isolated polymerized stilbenes, such as hopeaphenol, were found to inhibit the viability of cancer cells [52].

\section{Resveratrol Biosynthesis in Nature}

Stilbenes are plant secondary metabolites built from joining two aromatic rings with an ethylene bridge (1,2-diphenylethylene backbone) to form the basic C6-C2-C6 skeleton. Stilbenes share many similarities in their structure, biosynthesis, and biological activities with phenylpropanoids and flavonoids, which originate from the same pathway. The key components for biosynthesis of stilbenes are malonyl-CoA, phenylalanine, and tyrosine (Figure 2). In glycolysis pathway, glucose is converted into pyruvic acid, which leads to acetyl coenzyme A. The latter is the precursor of malonyl-CoA, which plays an essential role in biosynthesis pathways for many secondary plant compounds. The condensation of erythrose-4-phosphate (four carbons), which is generated from the pentose phosphate pathway (parallel reaction pathway to glycolysis) and phosphoenol pyruvate (three carbons, an intermediate in glycolysis), yields the seven-carbon shikimate skeleton. The latter compound is then used in the shikimic acid pathway to generate the aromatic amino acids phenylalanine and tyrosine $[1,53]$.

The biosynthesis pathway for resveratrol starts with phenylalanine or tyrosine, as shown in Figure 2. The first step is to obtain para-coumaric acid from both pathways. The 
phenylalanine ammonia-lyase (PAL) transforms phenylalanine into cinnamic acid, which is further processed to generate 4-coumaric acid (para-coumaric acid) using cinnamate4-hydroxylase $(\mathrm{C} 4 \mathrm{H})$. Tyrosine ammonia-lyase (TAL) can directly generate $p$-coumaric acid from tyrosine. The second step includes transformation of para-coumaric acid into para-coumaroyl-CoA by para-coumaroyl coenzyme A ligase (4CL). The final step involves the condensation of three units of malonyl-CoA with $p$-coumaroyl-CoA through stilbene synthase (STS) $[1,19,54]$.

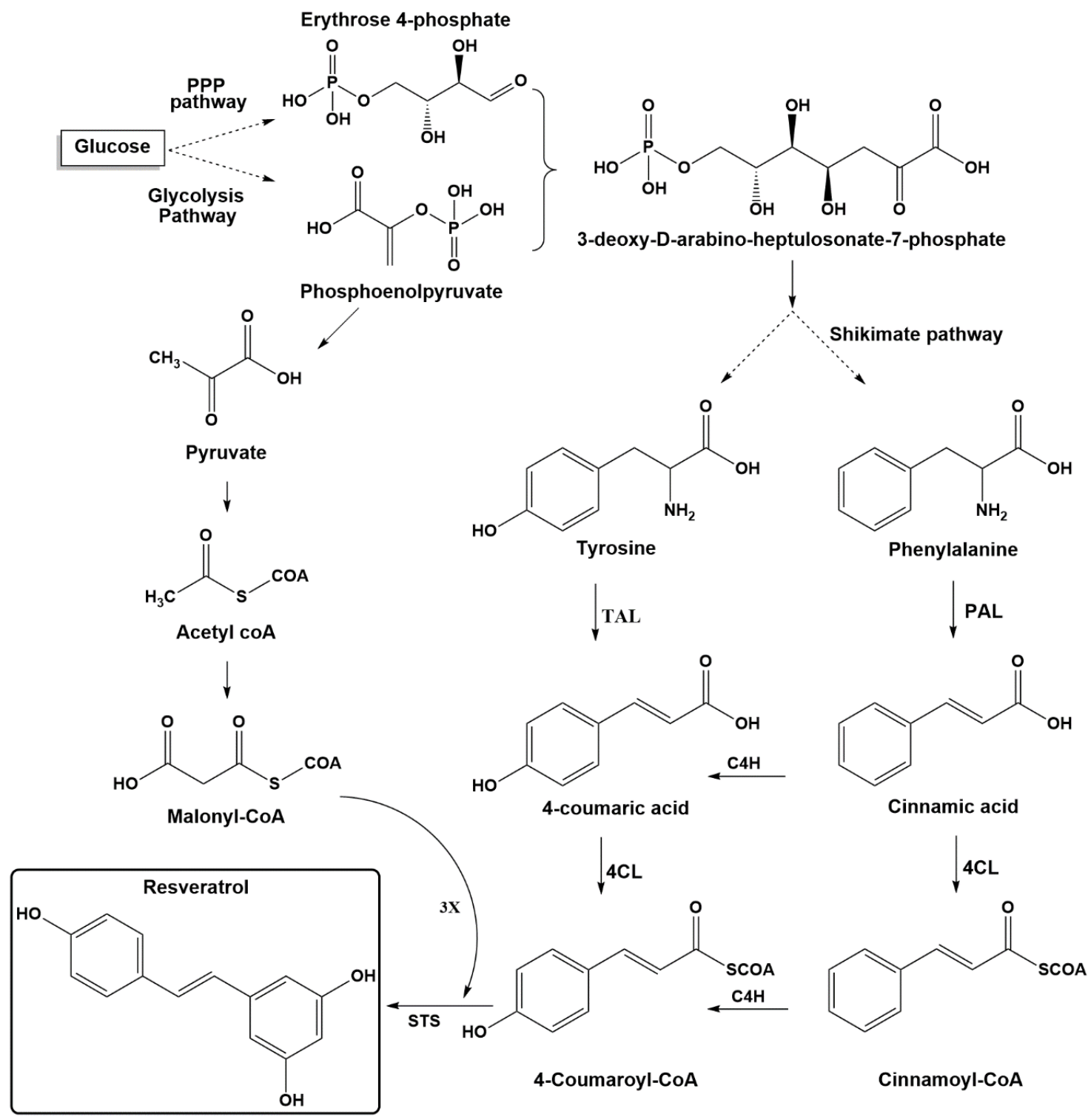

Figure 2. Resveratrol biosynthesis via the phenylalanine/tyrosine pathway. PPP: pentose phosphate pathway, TAL: tyrosine ammonia-lyase, PAL: phenylalanine ammonia lyase, C4H: cinnamate 4-hydroxylase, 4CL: 4-coumaroyl-coA ligase, STS: stilbene synthase.

The STS genes are usually expressed when induced by biotic or abiotic stimuli [55]. Although STS genes are limited to a few plant families, the Cyperaceae, Dipterocarpaceae, Fabaceae, Gnetaceae, Pinaceae, and Vitaceae families have been reported to have a high degree of STS expression [56,57]. Sequencing of the genome of Vitis vinifera led to a broad diversification of the STS genes; at least 33 full-length coding genes were identified [58], which suggests complex regulation pathways, including the action of various transcription factors such as MYB and WRKY [59-61]. 
Starting from resveratrol, more modifications can be accomplished on its structure by various decorating enzymes. Many stilbene derivatives possess antioxidant and antifungal activities after methylation [62] or glucosylation of the aromatic hydroxyl groups [63]. Polyphenolic secondary metabolites can also be obtained from the oxidation of resveratrol by peroxidases and laccases, allowing for 2-8 resveratrol molecules to condensate [55].

\section{Resveratrol Production by Transgenic Yeasts}

Due to resveratrol's pharmacological importance and its possible health and disease applications, resveratrol large-scale production has become a necessity. In nature, plants are the resource for resveratrol production; however, their production is limited by high costs; low quantities (the highest resveratrol concentration in plants was found in the seeds of Paeonia suffruticosa Andr. var. papaveracea (Andr.) Kerner with titers of 0.87 g/kg) [64]; lack of plant sources; and difficulties in the extraction, purification, and concentration processes. Transgenic plants and plant cell suspensions are two methods used for resveratrol production. Although engineered plants are usually restricted to enhancing the expression of STS genes and they have high productivity (up to $650 \mathrm{mg} / \mathrm{kg}$ FW of resveratrol), the use of elicitors, long production times, purity, and engineering process difficulties compared with microorganisms, remain as drawbacks for using this method [65]. Similar to transgenic plants, plant cell suspensions need elicitors to induce cells to produce resveratrol with resveratrol titer up to $5 \mathrm{~g} / \mathrm{L}$. The major limitation of this method is the requirement of light, which is not possible in large-scale production [66]. Although a high yield of resveratrol can be achieved by chemical synthesis, the production steps are complex, and the production of byproducts and the required toxic organic solvents are major drawbacks for large-scale preparations [67].

Microorganisms have been essential sources for producing pharmaceutically and industrially important compounds for decades due to low-cost cultures, fast production, the ability to construct purification processes, the ease of manipulating their genetic components, as well as the availability of protein and metabolic engineering tools [68]. Yeasts provide a more suitable platform for resveratrol production compared with bacterial hosts. As eukaryotic organisms, yeast species have the ability to express genes coding for plant-derived enzymes, such as cytochrome P450 enzymes; to perform post-translational modification (such as glycosylation); and to functionally fold the eukaryotic recombinant protein [69,70]. Additionally, yeasts and plants share similar intracellular compartments such as the endoplasmic reticulum, which supports eukaryotic and membrane proteins biosynthesis [71]. Another advantage of using yeasts is that Saccharomyces cerevisiae (the most-used yeast species for resveratrol production) is a food-grade organism that can be used safely in human nutrition and pharmaceutical products [72].

$S$. cerevisiae is a well-studied microorganism model for industrial and pharmaceutical applications. Metabolic engineering of $S$. cerevisiae was recognized as a robust strategy to produce several plant-derived chemicals [73]. Yarrowia lipolytica is another yeast that has received industrial interest for more than 50 years due to its organic acids production ability. Y. lipolytica is an oleaginous, non-pathogenic yeast that can accumulate lipids up to $40 \%$ of its dry cell weight (DCW) and is considered a model organism in diverse research areas [74,75]. Similar to $S$. cerevisiae, Y. lipolytica is classified as a generally recognized as safe organism (GRAS); therefore, it has the potential to be used in food and pharmaceutical industries. They are also considered powerful hosts for expressing heterologous genes $[70,76]$; consequently, both are strong candidates for use as cell factories for resveratrol production. Since microorganisms, including yeasts, cannot naturally produce resveratrol, genetic engineering of these strains by heterologous genes is required. Selecting genes to be transferred and the appropriate enzymes were found to markedly affect resveratrol production. Furthermore, pathway engineering, mutagenesis, codon optimization, protein engineering, and using synthetic scaffolds are all different strategies used to enhance resveratrol production capabilities in yeasts. Table 1 lists the genes used to engineer some yeast strains for resveratrol production. 


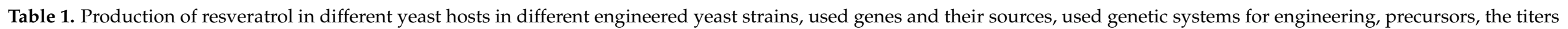
obtained, and the applied scale.

\begin{tabular}{|c|c|c|c|c|c|c|c|c|}
\hline $\begin{array}{l}\text { Yeast/Parent } \\
\text { Strain }\end{array}$ & Pathway Genes (Source) & $\begin{array}{l}\text { Pathway/Host } \\
\text { Engineering }\end{array}$ & Genetic System & Precursor & Titer (mg/L) & Scale & $\begin{array}{c}\text { Year of } \\
\text { Publication }\end{array}$ & Reference \\
\hline S. cerevisiae FY23 & $\begin{array}{c}\text { 4CL216 }(\text { P. trichocarpa } \times \text { P. deltoides }) \\
\text { VTS1 }(V . \text { vinifera })\end{array}$ & - & Episomal plasmid & $p$-Coumaric acid & 0.00145 & Flask & 2003 & {$[77]$} \\
\hline $\begin{array}{l}\text { S. cerevisiae } \\
\text { CEN-PK113-3B }\end{array}$ & $\begin{array}{l}\text { 4CL2 }(\text { N. tabacum }) \\
\text { STS }(\text { V. vinifera })\end{array}$ & - & $\begin{array}{l}\text { One copy genome } \\
\text { integration }\end{array}$ & $p$-Coumaric acid & 5.8 & Flask & 2006 & {$[78]$} \\
\hline S. cerevisiae WAT11 & $\begin{array}{c}\text { TAL }(\text { R. sphaeroides }) \\
\text { 4CL }(\text { A. thaliana) }:: S T S \text { ( } V . \text { vinifera })\end{array}$ & - & Episomal plasmid & $p$-Coumaric acid & 5.25 & Flask & 2006 & [79] \\
\hline $\begin{array}{c}\text { Industrial } \\
\text { Brazilian yeast } \\
\text { (S. cerevisiae) }\end{array}$ & $\begin{array}{l}\text { 4CL1 }(\text { A. thaliana }) \\
\text { STS }(\text { V. vinifera })\end{array}$ & - & Episomal plasmid & $p$-Coumaric acid & $262-391$ & Flask & 2010 & [81] \\
\hline $\begin{array}{l}\text { S. cerevisiae } \\
\text { W303-1A }\end{array}$ & $\begin{array}{l}\text { 4CL1 (A. thaliana) } \\
\text { STS (A. hypogaea) }\end{array}$ & PAD1 knockout & Episomal plasmid & $p$-Coumaric acid & 3.1 & Flask & 2011 & [82] \\
\hline $\begin{array}{l}\text { S. cerevisiae } \\
\text { W303-1A }\end{array}$ & $\begin{array}{c}\text { PAL }(\text { R. toruloides }) \\
\text { C4H, 4CL1 }(\text { A. thaliana }) \\
\text { STS }(\text { A. hypogaea })\end{array}$ & $\begin{array}{l}\text { Overexpression of } \\
\text { ACC1 }\end{array}$ & Episomal plasmid & Tyrosine & 5.8 & Batch bioreactor & 2012 & [84] \\
\hline S. cerevisiae WAT11 & $\begin{array}{l}\text { 4CL1 }(\text { A. thaliana }) \\
\text { STS }(V . \text { vinifera })\end{array}$ & Synthetic scaffold & Episomal plasmid & $\begin{array}{l}p \text {-Coumaric } \\
\text { acid }\end{array}$ & 14.4 & Flask & 2012 & [85] \\
\hline S. cerevisiae WAT11 & $\begin{array}{c}\text { 4CL::STS, } 4 \text { CL1 (A. thaliana)-STS ( } V . \\
\text { vinifera) fusion enzyme }\end{array}$ & $\begin{array}{l}\text { Overexpression of: } \\
\text { AAE13 }\end{array}$ & $\begin{array}{l}\text { One copy genome } \\
\text { integration }\end{array}$ & $p$-Coumaric acid & Up to 3.7 & Flask & 2014 & [86] \\
\hline $\begin{array}{l}\text { S. cerevisiae } \\
\text { EC1118 }\end{array}$ & $\begin{array}{l}\text { 4CL }(\text { A. thaliana }) \\
\text { STS }(V . \text { vinifera })\end{array}$ & - & $\begin{array}{l}\text { Episomal } \\
\text { plasmids }\end{array}$ & $p$-coumaric acid & 8.249 & Flask & 2015 & [87] \\
\hline
\end{tabular}


Table 1. Cont

\begin{tabular}{|c|c|c|c|c|c|c|c|c|}
\hline $\begin{array}{c}\text { Yeast/Parent } \\
\text { Strain }\end{array}$ & Pathway Genes (Source) & $\begin{array}{l}\text { Pathway/Host } \\
\text { Engineering }\end{array}$ & Genetic System & Precursor & Titer (mg/L) & Scale & $\begin{array}{c}\text { Year of } \\
\text { Publication }\end{array}$ & Reference \\
\hline $\begin{array}{c}\text { S. cerevisiae CEN. } \\
\text { PK102-5B }\end{array}$ & $\begin{array}{c}\text { TAL }(\text { H. aurantiacus }) \\
\text { TAL }(\text { F. johnsoniae }) \\
\text { 4CL1 and 4CL2 (A. thaliana) } \\
\text { RS }(\text { V. vinifera })\end{array}$ & $\begin{array}{l}\text { Overexpression of } \\
\mathrm{ARO} 4^{\mathrm{fbr}}, \mathrm{ARO} 7^{\mathrm{fbr}}, \\
\text { and } \mathrm{ACC} 1\end{array}$ & $\begin{array}{l}\text { Multiple copy } \\
\text { genome } \\
\text { integration }\end{array}$ & $\begin{array}{l}\text { Glucose } \\
\text { Ethanol }\end{array}$ & $\begin{array}{l}415.65 \\
531.41\end{array}$ & $\begin{array}{l}\text { Fed-batch bioreactor } \\
\text { Fed-batch bioreactor }\end{array}$ & 2015 & [88] \\
\hline $\begin{array}{l}\text { S. cerevisiae CEN. } \\
\text { PK102-5B }\end{array}$ & $\begin{array}{c}\text { PAL2, C4H, 4CL2 (A. thaliana) } \\
\text { VST1 (V. vinifera) }\end{array}$ & $\begin{array}{c}\text { Overexpression of } \\
\text { ARO4 }^{\mathrm{fbr}} \text {, ARO7 }{ }^{\mathrm{fbr}}, \\
\text { ACC1, CYB5 (S. } \\
\text { cerevisiae), ATR2 } \\
\text { (A. thaliana), ACS } \\
\text { (S. enterica), and } \\
\text { deletion of aro10 }\end{array}$ & $\begin{array}{l}\text { Multiple-copy } \\
\text { genome } \\
\text { integration }\end{array}$ & $\begin{array}{l}\text { Glucose } \\
\text { Ethanol }\end{array}$ & $\begin{array}{l}812 \\
755\end{array}$ & $\begin{array}{l}\text { Fed-batch bioreactor } \\
\text { Fed-batch bioreactor }\end{array}$ & 2016 & [89] \\
\hline S. cerevisiae W303 & $\begin{array}{c}\text { 4CL1 (P. appendiculatum) } \\
\text { STS }(P . \text { henryana }) \\
\text { STS }(\text { P. cuspidatum }) \\
\text { STS (M. alba var. atropurpurea) } \\
\text { STS }(R \text {. tataricum }) \\
\text { STS }(\text { V. vinifera }) \\
\text { STS }(\text { A. hypogaea }) \\
\text { One STS gene for each yeast line }\end{array}$ & - & $\begin{array}{l}\text { Episomal } \\
\text { plasmids }\end{array}$ & $p$-Coumaric acid & $23.7-39.9$ & Batch bioreactor & 2020 & [90] \\
\hline \multirow{2}{*}{$\begin{array}{c}\text { Co-culture of } \\
\text { E. coli NEB10 } \beta \\
\text { and } \\
\text { S. cerevisiae BY4741 }\end{array}$} & TAL (T. cutaneum) & $\begin{array}{l}\text { Overexpression of } \\
\text { aroG and tyrA } \\
\text { in a tyrR knockout } \\
\text { strain }\end{array}$ & $\begin{array}{c}\text { Bacterial } \\
\text { Expression Vectors }\end{array}$ & Glucose & \multirow[t]{2}{*}{36} & \multirow{2}{*}{$\begin{array}{l}\text { Co-culture } \\
\text { fermentation }\end{array}$} & \multirow[t]{2}{*}{2020} & \multirow[t]{2}{*}{ [91] } \\
\hline & $\begin{array}{l}\text { 4CL }(\text { A. thaliana }) \\
\text { STS }(V . \text { vinifera })\end{array}$ & $\begin{array}{l}\text { Overexpression of: } \\
\text { ACC1 }\end{array}$ & $\begin{array}{l}\text { One copy genome } \\
\text { integration }\end{array}$ & $\begin{array}{l}p \text {-Coumaric acid } \\
\text { (secreted from } E . \\
\text { coli) }\end{array}$ & & & & \\
\hline $\begin{array}{l}\text { Y. lipolytica ATCC } \\
20362\end{array}$ & $\begin{array}{l}\text { PAL/TAL (R.glutinis) } \\
\text { 4CL (S. coelicolor) } \\
\text { STS }(V . \text { vinifera })\end{array}$ & - & & L-tyrosine & 1.46 & & 2010 & [92] \\
\hline
\end{tabular}


Table 1. Cont

\begin{tabular}{|c|c|c|c|c|c|c|c|c|}
\hline $\begin{array}{c}\text { Yeast/Parent } \\
\text { Strain }\end{array}$ & Pathway Genes (Source) & $\begin{array}{l}\text { Pathway/Host } \\
\text { Engineering }\end{array}$ & Genetic System & Precursor & Titer $(\mathrm{mg} / \mathrm{L})$ & Scale & $\begin{array}{c}\text { Year of } \\
\text { Publication }\end{array}$ & Reference \\
\hline Y. lipolytica & $\begin{array}{c}\text { 4CL (N. tabacum) } \\
\text { STS (A. hypogaea) }\end{array}$ & $\begin{array}{l}\text { Overexpression of: } \\
\text { ACC1, PEX10 }\end{array}$ & $\begin{array}{l}\text { Randomly } \\
\text { genome } \\
\text { integration }\end{array}$ & $p$-Coumaric acid & 48.7 & Flask & 2020 & [93] \\
\hline $\begin{array}{l}\text { Y. lipolytica Po1d } \\
(w t), \text { derived from } \\
\text { W29 }\end{array}$ & $\begin{array}{c}\text { TAL }(F . \text { johnsoniae }) \\
\text { PAL }(V \text {. vinifera }) \\
\text { C4H, 4CL1 (A. thaliana) } \\
\text { VST }(\text { V. vinifera })\end{array}$ & - & $\begin{array}{l}\text { Multiple copy } \\
\text { genome } \\
\text { integration }\end{array}$ & Glycerol & 430 & Bioreactor & 2020 & [94] \\
\hline $\begin{array}{l}\text { Y. lipolytica Po1fk } \\
\text { derived from W29 }\end{array}$ & $\begin{array}{l}\text { TAL }(\text { R. toruloides }) \\
\text { 4CL }(P . \text { crispum }) \\
\text { STS }(V . \text { vinifera })\end{array}$ & $\begin{array}{c}\text { ARO4 }^{\mathrm{fbr}}(\mathrm{S} . \\
\text { cerevisiae }) \\
\text { aroG }^{\mathrm{fbr}}(\text { E. coli }) \\
\text { xfpK }(\text { B. breve }) \\
\text { xpkA }(\text { A. } \\
\text { capsulatum }) \\
\text { Overexpression: of } \\
\text { ARO1, ARO2, } \\
\text { ARO3, ARO4, } \\
\text { ARO5, TKT } \\
\text { Deletion of: TRP2, } \\
\text { TRP3, ARO8, } \\
\text { ARO9, PYK, PHA2 }\end{array}$ & $\begin{array}{l}\text { One copy genome } \\
\text { integration }\end{array}$ & Glucose & 12.67 & Flask & 2020 & [95] \\
\hline $\begin{array}{l}\text { Y. lipolytica ST6512 } \\
\text { (W29) }\end{array}$ & $\begin{array}{l}\text { TAL }(F . \text { johnsoniae }) \\
\text { 4CL1 }(\text { A. thaliana }) \\
\text { VST1 }(\text { V. vinifera })\end{array}$ & $\begin{array}{l}\text { Overexpression of: } \\
\mathrm{ARO} 4^{\mathrm{fbr}} \text { and } \\
\mathrm{ARO} 7^{\mathrm{fbr}}\end{array}$ & $\begin{array}{l}\text { Multiple copy } \\
\text { genome } \\
\text { integration }\end{array}$ & $\begin{array}{l}\text { Glucose } \\
\text { Glucose }\end{array}$ & $\begin{array}{c}409 \\
12355\end{array}$ & $\begin{array}{c}\text { Flask } \\
\text { Fed-batch bioreactor }\end{array}$ & 2020 & [96] \\
\hline Ogataea polymorpha & $\begin{array}{l}\text { TAL }(\text { H. aurantiacus }) \\
\text { 4CL }(\text { A. thaliana }) \\
\text { STS }(\text { V. vinifera })\end{array}$ & - & $\begin{array}{l}\text { CRISPR-Cas9- } \\
\text { assisted multiplex } \\
\text { genome editing, } \\
\text { multi-copy } \\
\text { integration }\end{array}$ & Tyrosine & 97.23 & Flask & 2018 & [97] \\
\hline
\end{tabular}




\subsection{Pathway Engineering}

The introduction of an entire biosynthetic pathway into the microorganism provides the ability to produce resveratrol from its precursors (L-phenylalanine or L-tyrosine) or lowcost materials such as glycerol, glucose, or ethanol $[19,89,98]$. In this method, PAL or TAL, depending on the used pathway; $\mathrm{C} 4 \mathrm{H} ; 4 \mathrm{CL}$; and STS encoding genes are transferred into the chosen host. One of the first attempts to entirely reconstruct the resveratrol pathway was conducted by Zhang et al. in 2006 in S. cerevisiae. TAL from Rhodobacter sphaeroides, in 4CL from Arabidopsis thaliana, and in STS from $V$. vinifera (4CL::STS fusion protein) were introduced into the $S$. cerevisiae strain WAT11. Although the TAL gene was not expressed in the yeast, after $20 \mathrm{~h}, 5.25 \mu \mathrm{g} / \mathrm{mL}$ of resveratrol was detected. The expression of the coupled genes coding for the fusion protein increased the resveratrol titer up to 15-fold compared with the co-expression of the genes encoding the separate enzymes, which emphasized the importance of the fusion protein and the spatial localization of these two related enzymes to improve resveratrol production [79]. Similarly, the same strain carrying TAL codonoptimized from $R$. sphaeroides and a similar fusion enzyme 4CL::STS were able to produce a resveratrol titer of $1.06 \mathrm{mg} / \mathrm{L}$ without the addition of L-tyrosine, and $1.90 \mathrm{mg} / \mathrm{L}$ with tyrosine. Again, the fused protein significantly increased resveratrol biosynthesis [83].

Production of resveratrol by the phenylalanine pathway was reported in S. cerevisiae YPH499. A strain harboring PAL from Populus trichocarpa, C4H and 4CL from Glycine max, and STS from $V$. vinifera produced resveratrol after being fed with phenylalanine, but the titer was still low $(0.29 \mathrm{mg} / \mathrm{L})$ [80]. The combination of both pathways was established in Y. lipolytica, and the final titer obtained was $1.46 \mathrm{mg} / \mathrm{L}$ [92]. In a recent study, Y. lipolytica was engineered using TAL from Flavobacterium johnsoniae, PAL and STS from $V$. vinifera, and $\mathrm{C} 4 \mathrm{H}$ and $4 \mathrm{CL} 1$ from $A$. thaliana. The strains showed the ability to produce resveratrol using both pathways separately (using tyrosine or phenylalanine as precursors) or in combination. The importance of gene overexpression by increasing the gene copy number in the resveratrol pathway was clearly demonstrated in this study, in which strains harboring two copies of the PAL, C4H, 4CL1, and STS genes or two copies of TAL, 4CL1, and STS exhibited higher performances than single-copy sets of genes. The best results were obtained from a strain containing two copies of PAL, C4H, TAL, 4CL1, and STS, which produced a high titer of resveratrol, reaching $450 \mathrm{mg} / \mathrm{L}$ under fermentation conditions using $100 \mathrm{~g} / \mathrm{L}$ glycerol as the sole carbon source, which is the highest reported amount of resveratrol produced from the expression of only the resveratrol pathway [94].

Engineering partial pathways or selected genes is an alternative strategy to produce resveratrol. In this case, PAL, TAL, and $\mathrm{C} 4 \mathrm{H}$ are usually excluded from the pathway construction, and para-coumaric acid is used as the precursor. S. cerevisiae FY23 was the first used for resveratrol pathway construction in yeast. The 4CL216 from a hybrid poplar and vst1 from a grape vine were constitutively expressed in the strain. After feeding with $5 \mathrm{mM} p$-coumaric acid, the recombinant strain produced $1.45 \mu \mathrm{g} / \mathrm{L}$ resveratrol [77]. Higher resveratrol titers were then obtained from S. cerevisiae strains CEN-PK113-3B and EC1118, which harbor Nt4CL2 and At4CL2, respectively, and VvSTS. The two strains using $p$-coumaric acid as a precursor produced 5.8 and $8.2 \mathrm{mg} / \mathrm{L}$ resveratrol, respectively, as a final product $[78,87]$.

Using synthetic scaffolds is another strategy used for improving resveratrol production. Nine different constructions containing GTPase binding domain (GBD), Src homology 3 domain (SH3) with 4CL1 from A. thaliana, and PSD95/DlgA/Zo-1 domain (PDZ) with STS from $V$. vinifera were recruited and optimized in S. cerevisiae WAT11 cells. Resveratrol production in the transformed yeast cells containing the optimal scaffold $\left(\mathrm{GBD}_{1} \mathrm{SH}_{2} \mathrm{PDZ}_{4}\right)$ showed a five-fold increase in the production after $36 \mathrm{~h}(6.7 \mathrm{mg} / \mathrm{L})$ and more than a two-fold rise in the resveratrol titer at $96 \mathrm{~h}$ after induction $(14.4 \mathrm{mg} / \mathrm{L})$. Using this scaffold strategy increased the resveratrol titer by 2.7 -fold compared with the fusion enzyme strategy for the same genes $[79,85]$. This indicates the effectiveness of protein scaffolds in improving resveratrol synthesis and in increasing pathway enzyme activity compared with the protein fusions strategy. 
The importance of selecting pathway genes and codon-optimizing them was explored in a recent report, in which six STS genes from different sources (PhStS, PcPKS5, MaSTS3, RtSTS, VvVST1, and AhSTS) were codon-optimized and then co-expressed with 4CL from Plagiochasma appendiculatum in S. cerevisiae W303. Differences in production time for the final yield were observed among the different strains. Although the lines expressing VvVST1, AhSTS, and RtSTS genes produced resveratrol quickly, their final titer was rather low $(27-30 \mathrm{mg} / \mathrm{L})$. Conversely, strains harboring STS from Morusalba and P. cuspidatum accumulated resveratrol up to $39 \mathrm{mg} / \mathrm{L}$ using $70 \mathrm{mg} / \mathrm{L} p$-coumaric acid [86]. Codon optimization for resveratrol pathway genes has also been observed in several studies in both S. cerevisiae and Y. lipolytica $[88,91,93,95,96]$. The highest resveratrol titer, which was produced by the expression of partial pathway genes (4CL and STS) in yeasts, was obtained from industrial Brazilian sugar-cane-fermenting yeast, and the titer was $391 \mathrm{mg} / \mathrm{L}$ of resveratrol [81].

\subsection{Host Metabolic Engineering (Non-Pathway Genes)}

Metabolic engineering of microbial hosts for resveratrol production has achieved significant progress in recent years. The main remaining obstacles for microbial production of resveratrol are the precursor availability and the low activity of stilbene synthase in heterologous hosts. Hence, the primary strategies for increasing productivity using microbial cell factories are increasing the precursor supply (aromatic amino acids and malonyl-CoA) via genetic manipulation of the strain and improving the activity of key enzymes via protein engineering.

To increase the precursor levels, the introduction of non-pathway exogenous genes and pathway redirection are crucial. Notable efforts have been dedicated to optimizing the aromatic amino acids production and their derived phenylpropenoic acids in yeast $[99,100]$. Overproduction of aromatic amino acids can be easily achieved by engineering the shikimate pathway. Metabolic engineering of this pathway focused on improving carbon flux toward chorismate, and then Phe and Tyr (Figure 3). Extending the E4P and PEP supply and availability are considered fundamental approaches to enhancing chorismate production [73]. Intracellular malonyl-CoA is the other prime precursor involved in resveratrol biosynthesis. Naturally, the majority of malonyl-CoA is used in fatty acid biosynthesis, leaving a minimal level to be used in resveratrol biosynthesis. Thus, increasing this precursor in microbial hosts provides the opportunity for extra enhancement in resveratrol biosynthesis in the host platform.

Two main strategies are usually applied to enhance the malonyl-CoA pool. The first is to improve acetyl-CoA carboxylation into malonyl-CoA via the acetyl-CoA carboxylase (ACC) enzyme. The other strategy is to inhibit malonyl-CoA consumption by repressing the biosynthesis of fatty acids (Figure 3) [101]. Since the blocking of malonyl-CoA consumption and direct knockouts of the fab genes were found to be lethal to microorganisms [102], the inhibition has been accomplished in bacterial hosts via three procedures: the addition of cerulenin antibiotic to inhibit FabB and FabF $[103,104]$; using antisense RNA to repress the $f a b$ operon, especially the $f a b D$ genes [102,105]; and the CRISPRi tool, considered the third promising approach for repressing $f a b$ genes and directing carbon flux to malonylCoA [106,107]. Although these approaches have only been implemented in E. coli, they might provide valuable tools for future studies on increasing the precursors for resveratrol in yeast strains. S. cerevisiae is known to metabolize $p$-coumaric acid into 4 -vinylphenol by phenyl acrylic acid decarboxylase (Pad1p). Although a PAD1 knockout mutation in S. cerevisiae W303-1A repressed the consumption of $p$-coumaric acid compared with the wild-type strain that uses about $60 \%$ of the $p$-coumaric acid, no enhancement was detected in resveratrol production $(3.1 \mathrm{mg} / \mathrm{L})$ when the PAD1 deletion mutant strain was transformed with a plasmid harboring At4CL1 and AhSTS [82]. In a separate study, the same strain (without PAD1 knockout mutation) was further transferred with RtPAL and $\mathrm{AtC} 4 \mathrm{H}$ genes to produce $2.6 \mathrm{mg} / \mathrm{L} p$-coumaric acid and $3.3 \mathrm{mg} / \mathrm{L}$ resveratrol, which indicates the minor effect of this strategy in increasing resveratrol production. The ACC1 
gene was then overexpressed to increase the malonyl-CoA pool, which was reflected in the increase in resveratrol production to $4.3 \mathrm{mg} / \mathrm{L}$ without amino acids addition, and up to $5.8 \mathrm{mg} / \mathrm{L}$ with tyrosine added [84]. The overexpression of ACC1 was similarly reported in an E. coli-S. cerevisiae co-culture and Y. lipolytica for resveratrol production [91,93]. An increasing malonyl-CoA pool was also achieved by the overexpression of a plant malonylCoA synthetase (AAE13), resulting in a 2.4-fold increase and accumulation in resveratrol in S. cerevisiae [86].

Increasing the phenylalanine precursor in the prephenic acid pathway was achieved by overexpression of feedback-insensitive alleles encoding DAHP synthase (ScARO4 ${ }^{\mathrm{K} 229 \mathrm{~L}}$ ) and chorismate mutase $\left(\mathrm{ScARO} 7^{\mathrm{G} 141 \mathrm{~S}}\right)$. Applying this strategy increased resveratrol production from 2.73 to $4.85 \mathrm{mg} / \mathrm{L}$ in S. cerevisiae with HaTAL, At4CL1, At4CL2, and VvVST1. The overexpression of the ScACC1 $1659 \mathrm{~A}$, S1157A gene raised the resveratrol titer to $6.39 \mathrm{mg} / \mathrm{L}$, and another improvement was produced by the multiple-copies integration of pathways genes, which produced the highest titer of $235.57 \mathrm{mg} / \mathrm{L}$, being 36-fold higher than in the last strain. Eventually, 415.65 and $531.41 \mathrm{mg} / \mathrm{L}$ of resveratrol were produced from the final strain under fed-batch fermentation with glucose or ethanol as the carbon source, respectively [88]. The same previous strategies were used with the phenylalanine pathway (AtPAL2, AtC4H, At4CL2, and VvVST1) with further metabolic engineering. Overexpression of cytochrome P450 reductase (AtATR2), S. cerevisiae cytochrome B5 (CYB5), and acetyl-CoA synthase (SeACS ${ }^{\mathrm{L} 641 \mathrm{P}}$ ) was used to increase the precursor supply, as well the deletion of phenylpyruvate decarboxylase (ARO10) to eliminate phenylalanine competing pathways. After this extensive engineering and cultivation in a fed-batch reactor, the strain was able to produce 812 and $755 \mathrm{mg} / \mathrm{L}$ of resveratrol from glucose and ethanol, respectively [89].

Y. lipolytica was proven to be a highly promising yeast for producing resveratrol. In Y. lipolytica ST6512, several metabolic strategies were used to finally obtain a strain that produced $12.4 \mathrm{~g} / \mathrm{L}$ resveratrol, the highest reported resveratrol titer to date from de novo production. In addition to multiple integrations of resveratrol pathway genes (FjTAL, At4CL1, and VvVST1), feedback-insensitive YlARO4 ${ }^{K 221 L}$ and $Y l A R O 7^{G 139 S}$ were employed to enhance resveratrol production. Further improvement was achieved by optimizing the growth medium and fed-batch fermentation [96].

In bacterial hosts, increased precursor amounts were additionally achieved by overexpression of different genes, such as malonyl-CoA synthetase (matB), malonate carrier protein (matC), tktA, PEP synthetase (ppsA), and acetate assimilation enzyme (acs), or by deleting or inhibiting competing pathway genes such as the $p t a, a c k A, a d h E, \operatorname{tyr} R, \operatorname{trp} R$, and $f a b$ genes. These strategies might enhance resveratrol production, which requires further experiments on yeast platforms [73,103,104,108-111]. 


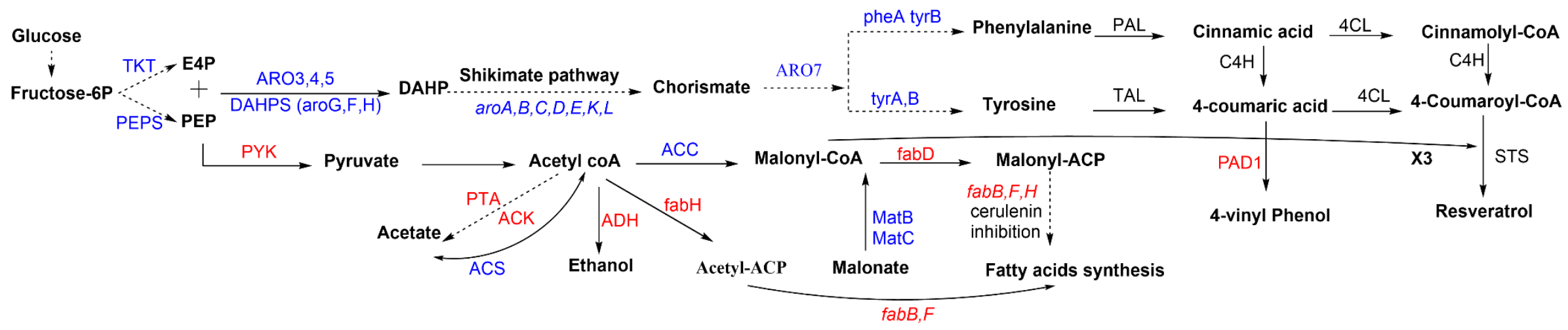

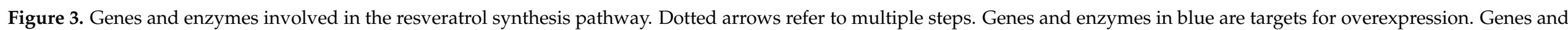

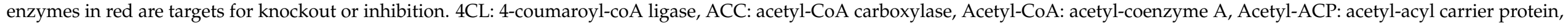

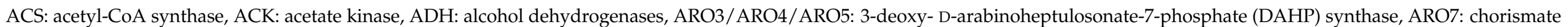

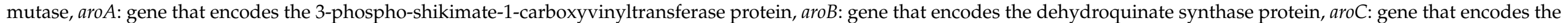

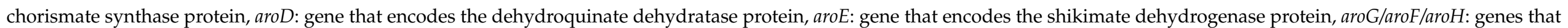

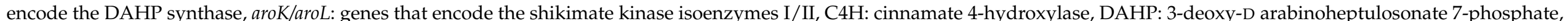

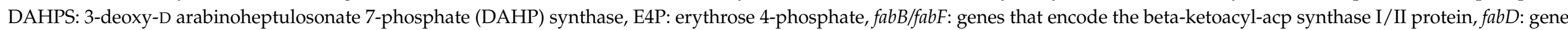

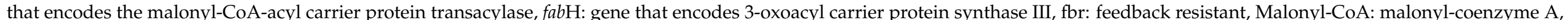

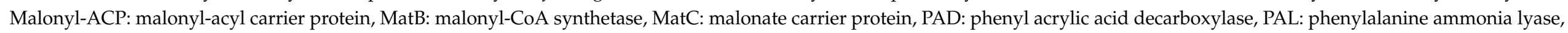

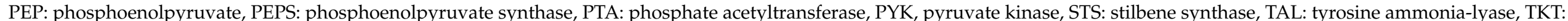
transketolase, tyrA/pheA: genes that encode the chorismate mutase protein, tyrB: gene that encodes the tyrosine aminotransferase. 


\section{Conclusions}

The increased demand for resveratrol for pharmaceutical and cosmetic uses necessitates its production from sustainable sources. Yeast cells are advantageous platforms for resveratrol production because of their fast production, the ease of their cultivation and purification processes, and their remarkable potential for large-scale resveratrol production. Due to their nature as eukaryotic cells and as GRAS organisms, the S. cerevisiae and $Y$. lipolytica platforms are preferable for resveratrol production. The successful design of a resveratrol production pathway depends on several factors, including determining the appropriate host, examining alternative specific enzymes from various sources, optimizing the codons to maximize the expression of heterologous genes, selecting a convenient transfer gene system (plasmids and their associated genetic elements), and determining favorable culturing parameters. Metabolic engineering has also achieved significant progress in increasing the resveratrol precursors, an important limitation in resveratrol production. Despite these efforts and extensive strain engineering, heterologous stilbene synthase activity and the overall resveratrol production are relatively still low. Except for one study that produced $12 \mathrm{~g} / \mathrm{L}$ of resveratrol from Y. lipolytica [96], almost all engineered yeast strains do not produce more than $1 \mathrm{~g} / \mathrm{L}$, which does not meet the industrial needs and is the main drawback for their use on an industrial scale. Applying all of these elements together in a balanced way as well as testing other strategies that have been applied in E. coli may allow scientists to obtain the desired well-designed resveratrol-producing strain.

Author Contributions: G.G.I. drafted the original manuscript, Y.Y. and J.Y. revised and L.X. and M.Y. corrected the manuscript. All authors have read and agreed to the published version of the manuscript.

Funding: This work was supported by funding by the National Natural Science Foundation of China (grant number: NSFC31570793), by the Fundamental Research Funds for the Central Universities (grant number: 2016YXMS255), and by the Startup Fund for Talent Scholars of Huazhong University of Science and Technology.

Acknowledgments: It was funded by the National Natural Science Foundation of China (Nos. 31971206 and 31170078).

Conflicts of Interest: The authors declare no conflict of interest.

\begin{tabular}{|c|c|}
\hline $4 \mathrm{CL}$ & 4-coumaroyl-coA ligase \\
\hline AAE13 & malonyl-CoA synthetase \\
\hline Acetyl-CoA & acetyl-coenzyme A \\
\hline Acetyl-ACP & acetyl-acyl carrier protein \\
\hline ACC & acetyl-CoA carboxylase \\
\hline ACS & acetyl-CoA synthase \\
\hline ACK & acetate kinase \\
\hline $\mathrm{ADH}$ & alcohol dehydrogenases \\
\hline araE & arabinose transporter \\
\hline ARO1 & multifunctional AROM complex \\
\hline $\mathrm{ARO} 2$ & chorismate synthase \\
\hline $\mathrm{ARO} 3 / \mathrm{ARO} 4 / \mathrm{ARO} 5$ & 3-deoxy- D-arabinoheptulosonate-7-phosphate (DAHP) synthase \\
\hline ARO7 & chorismate mutase \\
\hline ARO8 & aromatic amino acid aminotransferase I \\
\hline ARO9 & aromatic amino acid aminotransferase II \\
\hline ARO10 & transaminated amino acid decarboxylase \\
\hline $\operatorname{aro} A$ & $\begin{array}{l}\text { gene that encodes the 3-phospho-shikimate-1-carboxyvinyltransferase } \\
\text { protein }\end{array}$ \\
\hline $\operatorname{aroB}$ & gene that encodes the dehydroquinate synthase protein \\
\hline $\operatorname{aroC}$ & gene that encodes the chorismate synthase protein \\
\hline $\operatorname{aro} D$ & gene that encodes the dehydroquinate dehydratase protein \\
\hline
\end{tabular}




\begin{tabular}{|c|c|}
\hline $\operatorname{aroE}$ & gene that encodes the shikimate dehydrogenase protein \\
\hline aroG/aroF/aroH & genes that encode the DAHP synthase \\
\hline aroK/aroL & genes that encode the shikimate kinase isoenzymes I/II \\
\hline ATR2 & NADPH-cytochrome P450 reductase 2 \\
\hline $\mathrm{C} 4 \mathrm{H}$ & cinnamate 4-hydroxylase \\
\hline CPR & cytochrome P450 reductase \\
\hline CYB5 & cytochrome b5 \\
\hline DAHP & 3-deoxy-D arabinoheptulosonate 7-phosphate \\
\hline DAHPS & 3-deoxy-D arabinoheptulosonate 7-phosphate (DAHP) synthase \\
\hline E4P & erythrose 4-phosphate \\
\hline$f a b B / f a b F$ & genes that encode the beta-ketoacyl-acp synthase I/II protein \\
\hline$f a b D$ & gene that encodes the malonyl-CoA-acyl carrier protein transacylase \\
\hline $\mathrm{fabH}$ & gene that encodes 3-oxoacyl carrier protein synthase III \\
\hline fbr & feedback resistant \\
\hline GRAS & generally recognized as safe \\
\hline Malonyl-CoA & malonyl-coenzyme A \\
\hline Malonyl-ACP & malonyl-acyl carrier protein \\
\hline MatB & malonyl-CoA synthetase \\
\hline MatC & malonate carrier protein \\
\hline PAD & phenyl acrylic acid decarboxylase \\
\hline PAL & phenylalanine ammonia lyase \\
\hline PEP & phosphoenolpyruvate \\
\hline PEPS & phosphoenolpyruvate synthase \\
\hline PEX10 & peroxisomal biogenesis factor 10 \\
\hline PHA2 & prephenate dehydratase \\
\hline PPP & pentose phosphate pathway \\
\hline PTA & phosphate acetyltransferase \\
\hline PYK & pyruvate kinase \\
\hline STS & stilbene synthase \\
\hline TAL & tyrosine ammonia-lyase \\
\hline TKT & transketolase \\
\hline TRP2 & anthranilate synthase \\
\hline TRP3 & indole-3-glycerol-phosphate synthase \\
\hline tyrA/pheA & genes that encode the chorismate mutase protein \\
\hline TyrA & chorismate mutase/prephenate dehydrogenase \\
\hline tyrB & gene that encodes the tyrosine aminotransferase \\
\hline TyrR & transcriptional regulatory protein \\
\hline VST/RS & resveratrol synthase \\
\hline xfpK/xpkA & phosphoketolase. \\
\hline
\end{tabular}

\section{References}

1. Jeandet, P.; Sobarzo-Sánchez, E.; Silva, A.S.; Clément, C.; Nabavi, S.F.; Battino, M.; Rasekhian, M.; Belwal, T.; Habtemariam, S.; Koffas, M. Whole-cell biocatalytic, enzymatic and green chemistry methods for the production of resveratrol and its derivatives. Biotechnol. Adv. 2020, 39, 107461. [CrossRef] [PubMed]

2. Gugleva, V.; Zasheva, S.; Hristova, M.; Andonova, V. Topical use of resveratrol: Technological aspects. Pharmacia 2020, 67, 89. [CrossRef]

3. Jeandet, P.; Delaunois, B.; Conreux, A.; Donnez, D.; Nuzzo, V.; Cordelier, S.; Clément, C.; Courot, E. Biosynthesis, metabolism, molecular engineering, and biological functions of stilbene phytoalexins in plants. Biofactors 2010, 36, 331-341. [CrossRef] [PubMed]

4. Rabesiaka, M.; Rakotondramasy-Rabesiaka, L.; Mabille, I.; Porte, C.; Havet, J.-L. Extraction of trans-resveratrol from red wine and optimization by response surface methodology. Sep. Purif. Technol. 2011, 81, 56-61. [CrossRef]

5. Jeandet, P.; Douillet-Breuil, A.-C.; Bessis, R.; Debord, S.; Sbaghi, M.; Adrian, M. Phytoalexins from the Vitaceae: Biosynthesis, phytoalexin gene expression in transgenic plants, antifungal activity, and metabolism. J. Agric. Food Chem. 2002, 50, $2731-2741$. [CrossRef]

6. Takaoka, M. Of the phenolic substrate of hellebore (Veratrum grandiflorum Loes. fil.). J. Fac. Sci. Hokkaido Imper. Univ. 1940, 3, 1-16.

7. Nonomura, S.; Kanagawa, H.; Makimoto, A. Chemical Constituents of Polygonaceous Plants. I. Studies on the Components of Ko-jo-kon. (Polygonum cuspidatum SIEB. et ZUCC.). Yakugaku Zasshi 1963, 83, 988-990. [CrossRef] 
8. Jeandet, P.; Bessis, R.; Gautheron, B. The production of resveratrol (3, 5, 4'-trihydroxystilbene) by grape berries in different developmental stages. Am. J. Enol. Vitic. 1991, 42, 41-46.

9. Lyons, M.M.; Yu, C.; Toma, R.; Cho, S.Y.; Reiboldt, W.; Lee, J.; van Breemen, R. Resveratrol in raw and baked blueberries and bilberries. J. Agric. Food Chem. 2003, 51, 5867-5870. [CrossRef]

10. Wang, Y.; Catana, F.; Yang, Y.; Roderick, R.; van Breemen, R.B. An LC-MS method for analyzing total resveratrol in grape juice, cranberry juice, and in wine. J. Agric. Food Chem. 2002, 50, 431-435. [CrossRef]

11. Shrikanta, A.; Kumar, A.; Govindaswamy, V. Resveratrol content and antioxidant properties of underutilized fruits. J. Food Sci. Technol. 2015, 52, 383-390. [CrossRef] [PubMed]

12. Mudnic, I.; Budimir, D.; Modun, D.; Gunjaca, G.; Generalic, I.; Skroza, D.; Katalinic, V.; Ljubenkov, I.; Boban, M. Antioxidant and vasodilatory effects of blackberry and grape wines. J. Med. Food 2012, 15, 315-321. [CrossRef] [PubMed]

13. Sales, J.M.; Resurreccion, A.V. Resveratrol in peanuts. Crit. Rev. Food Sci. Nutr. 2014, 54, 734-770. [CrossRef] [PubMed]

14. Pezzuto, J.M.; Moon, R.C.; Jang, M.-S.; Ouali, A.; Lin, S.; Barillas, K.S. Pharmaceutical Formulations of Resveratrol and Methods of Use Thereof. U.S. Patent US6414037B1, 2 July 2002.

15. Ratz-Łyko, A.; Arct, J. Resveratrol as an active ingredient for cosmetic and dermatological applications: A review. J. Cosmet. Laser Ther. 2019, 21, 84-90. [CrossRef] [PubMed]

16. Singh, G.; Pai, R.S. Recent advances of resveratrol in nanostructured based delivery systems and in the management of HIV/AIDS. J. Control. Release 2014, 194, 178-188. [CrossRef]

17. Ndiaye, M.; Philippe, C.; Mukhtar, H.; Ahmad, N. The grape antioxidant resveratrol for skin disorders: Promise, prospects, and challenges. Arch. Biochem. Biophys. 2011, 508, 164-170. [CrossRef]

18. Pangeni, R.; Sahni, J.K.; Ali, J.; Sharma, S.; Baboota, S. Resveratrol: Review on therapeutic potential and recent advances in drug delivery. Expert Opin. Drug Deliv. 2014, 11, 1285-1298. [CrossRef]

19. Jeandet, P.; Delaunois, B.; Aziz, A.; Donnez, D.; Vasserot, Y.; Cordelier, S.; Courot, E. Metabolic engineering of yeast and plants for the production of the biologically active hydroxystilbene, resveratrol. J. Biomed. Biotechnol. 2012, 2012, 1-14. [CrossRef]

20. Voloshyna, I.; Hussaini, S.M.; Reiss, A.B. Resveratrol in cholesterol metabolism and atherosclerosis. J. Med. Food 2012, 15, 763-773. [CrossRef]

21. Rauf, A.; Imran, M.; Butt, M.S.; Nadeem, M.; Peters, D.G.; Mubarak, M.S. Resveratrol as an anti-cancer agent: A review. Crit. Rev. Food Sci. Nutr. 2018, 58, 1428-1447. [CrossRef]

22. Varoni, E.M.; Lo Faro, A.F.; Sharifi-Rad, J.; Iriti, M. Anticancer molecular mechanisms of resveratrol. Front. Nutr. $2016,3,8$. [CrossRef]

23. Cai, H.; Scott, E.; Kholghi, A.; Andreadi, C.; Rufini, A.; Karmokar, A.; Britton, R.G.; Horner-Glister, E.; Greaves, P.; Jawad, D.; et al. Cancer chemoprevention: Evidence of a nonlinear dose response for the protective effects of resveratrol in humans and mice. Sci. Transl. Med. 2015, 7, ra117-ra298. [CrossRef] [PubMed]

24. Carter, L.G.; D'Orazio, J.A.; Pearson, K.J. Resveratrol and cancer: Focus on in vivo evidence. Endocr. Relat. Cancer 2014, 21, R209-R225. [CrossRef] [PubMed]

25. de Sá Coutinho, D.; Pacheco, M.T.; Frozza, R.L.; Bernardi, A. Anti-inflammatory effects of resveratrol: Mechanistic insights. Int. J. Mol. Sci. 2018, 19, 1812. [CrossRef]

26. Zordoky, B.N.M.; Robertson, I.M.; Dyck, J.R.B. Preclinical and clinical evidence for the role of resveratrol in the treatment of cardiovascular diseases. Biochim. Biophys. Acta Mol. Basis Dis. 2015, 1852, 1155-1177. [CrossRef] [PubMed]

27. Malaguarnera, L. Influence of resveratrol on the immune response. Nutrients 2019, 11, 946. [CrossRef]

28. Prysyazhna, O.; Wolhuter, K.; Switzer, C.; Santos, C.; Yang, X.; Lynham, S.; Shah, A.M.; Eaton, P.; Burgoyne, J.R. Blood pressure lowering by the antioxidant resveratrol is counterintuitively mediated by oxidation of cGMP-dependent protein kinase. Circulation 2019, 140, 126-137. [CrossRef]

29. Rao, Y.L.; Ganaraja, B.; Joy, T.; Pai, M.M.; Ullal, S.D.; Murlimanju, B.V. Neuroprotective effects of resveratrol in Alzheimer's disease. Front. Biosci. 2020, 12, 139-149.

30. Bastianetto, S.; Ménard, C.; Quirion, R. Neuroprotective action of resveratrol. Biochim. Biophys. Acta (BBA) Mol. Basis Dis. 2015 1852, 1195-1201. [CrossRef] [PubMed]

31. Rege, S.D.; Geetha, T.; Griffin, G.D.; Broderick, T.L.; Babu, J.R. Neuroprotective effects of resveratrol in Alzheimer disease pathology. Front. Aging Neurosci. 2014, 6, 218. [CrossRef]

32. Singh, N.; Agrawal, M.; Doré, S. Neuroprotective Properties and Mechanisms of Resveratrol in in Vitro and in Vivo Experimental Cerebral Stroke Models. ACS Chem. Neurosci. 2013, 4, 1151-1162. [CrossRef] [PubMed]

33. Adhikari, N.; Prasad Aryal, Y.; Jung, J.-K.; Ha, J.-H.; Choi, S.-Y.; Kim, J.-Y.; Lee, T.-H.; Kim, S.-H.; Yamamoto, H.; Suh, J.-Y.; et al. Resveratrol enhances bone formation by modulating inflammation in the mouse periodontitis model. J. Periodontal Res. 2021, in press. [CrossRef]

34. Jeandet, P.; Clément, C.; Tisserant, L.-P.; Crouzet, J.; Courot, É. Use of grapevine cell cultures for the production of phytostilbenes of cosmetic interest. Comptes Rendus Chim. 2016, 19, 1062-1070. [CrossRef]

35. Tsai, M.-J.; Lu, I.J.; Fu, Y.-S.; Fang, Y.-P.; Huang, Y.-B.; Wu, P.-C. Nanocarriers enhance the transdermal bioavailability of resveratrol: In-vitro and in-vivo study. Colloids Surf. B Biointerfaces 2016, 148, 650-656. [CrossRef]

36. Pelliccia, M.; Giannella, A.; Giannella, J. Use of Resveratrol for the Treatment of Exfoliative Eczema, Acne and Psoriasis. U.S. Patent US20010056071A1, 27 December 2001. 
37. Baxter, R.A. Anti-aging properties of resveratrol: Review and report of a potent new antioxidant skin care formulation. J. Cosmet. Dermatol. 2008, 7, 2-7. [CrossRef]

38. Zhou, X.; Ruan, Q.; Ye, Z.; Chu, Z.; Xi, M.; Li, M.; Hu, W.; Guo, X.; Yao, P.; Xie, W. Resveratrol accelerates wound healing by attenuating oxidative stress-induced impairment of cell proliferation and migration. Burns 2021, 47, 133-139. [CrossRef] [PubMed]

39. Du, Q.-H.; Peng, C.; Zhang, H. Polydatin: A review of pharmacology and pharmacokinetics. Pharm. Biol. 2013, 51, 1347-1354. [CrossRef]

40. Lv, M.; Liu, K.; Fu, S.; Li, Z.; Yu, X. Pterostilbene attenuates the inflammatory reaction induced by ischemia/reperfusion in rat heart. Mol. Med. Rep. 2015, 11, 724-728. [CrossRef]

41. Aldawsari, F.S.; Velázquez-Martínez, C.A. 3,4',5-trans-Trimethoxystilbene; a natural analogue of resveratrol with enhanced anticancer potency. Investig. New Drugs 2015, 33, 775-786. [CrossRef]

42. McCormack, D.E.; Mannal, P.; McDonald, D.; Tighe, S.; Hanson, J.; McFadden, D. Genomic analysis of pterostilbene predicts its antiproliferative effects against pancreatic cancer in vitro and in vivo. J. Gastrointest. Surg. 2012, 16, 1136-1143. [CrossRef]

43. Sale, S.; Verschoyle, R.D.; Boocock, D.; Jones, D.; Wilsher, N.; Ruparelia, K.C.; Potter, G.A.; Farmer, P.B.; Steward, W.P.; Gescher, A.J. Pharmacokinetics in mice and growth-inhibitory properties of the putative cancer chemopreventive agent resveratrol and the synthetic analogue trans 3, 4, 5, 4'-tetramethoxystilbene. Br. J. Cancer 2004, 90, 736-744. [CrossRef] [PubMed]

44. Li, Q.; Chen, L.; Liu, X.; Li, X.; Cao, Y.; Bai, Y.; Qi, F. Pterostilbene inhibits amyloid- $\beta$-induced neuroinflammation in a microglia cell line by inactivating the NLRP3/caspase-1 inflammasome pathway. J. Cell. Biochem. 2018, 119, 7053-7062. [CrossRef]

45. Li, Y.-R.; Li, S.; Lin, C.-C. Effect of resveratrol and pterostilbene on aging and longevity. BioFactors 2018, 44, 69-82. [CrossRef] [PubMed]

46. Nivelle, L.; Hubert, J.; Courot, E.; Jeandet, P.; Aziz, A.; Nuzillard, J.-M.; Renault, J.-H.; Clément, C.; Martiny, L.; Delmas, D.; et al. Anti-cancer activity of resveratrol and derivatives produced by grapevine cell suspensions in a $14 \mathrm{~L}$ stirred bioreactor. Molecules 2017, 22, 474. [CrossRef] [PubMed]

47. González-Sarrías, A.; Gromek, S.; Niesen, D.; Seeram, N.P.; Henry, G.E. Resveratrol Oligomers Isolated from Carex Species Inhibit Growth of Human Colon Tumorigenic Cells Mediated by Cell Cycle Arrest. J. Agric. Food Chem. 2011, 59, 8632-8638. [CrossRef] [PubMed]

48. Barjot, C.; Tournaire, M.; Castagnino, C.; Vigor, C.; Vercauteren, J.; Rossi, J.-F. Evaluation of antitumor effects of two vine stalk oligomers of resveratrol on a panel of lymphoid and myeloid cell lines: Comparison with resveratrol. Life Sci. 2007, 81, 1565-1574. [CrossRef]

49. Muhtadi; Hakim, E.H.; Juliawaty, L.D.; Syah, Y.M.; Achmad, S.A.; Latip, J.; Ghisalberti, E.L. Cytotoxic resveratrol oligomers from the tree bark of Dipterocarpus hasseltii. Fitoterapia 2006, 77, 550-555. [CrossRef]

50. Chowdhury, S.A.; Kishino, K.; Satoh, R.; Hashimoto, K.; Kikuchi, H.; Nishikawa, H.; Shirataki, Y.; Sakagami, H. Tumor-specificity and apoptosis-inducing activity of stilbenes and flavonoids. Anticancer. Res. 2005, 25, 2055-2063.

51. Nivelle, L.; Hubert, J.; Courot, E.; Borie, N.; Renault, J.-H.; Nuzillard, J.-M.; Harakat, D.; Clément, C.; Martiny, L.; Delmas, D.; et al. Cytotoxicity of labruscol, a new resveratrol dimer produced by grapevine cell suspensions, on human skin melanoma cancer cell line HT-144. Molecules 2017, 22, 1940. [CrossRef]

52. Rohaiza, S.; Yaacob, W.; Din, L.; Nazlina, I. Cytotoxic oligostilbenes from Shorea hopeifolia. Afr. J. Pharm. Pharmacol. 2011, 5, 1272-1277. [CrossRef]

53. Nabavi, S.M.; Šamec, D.; Tomczyk, M.; Milella, L.; Russo, D.; Habtemariam, S.; Suntar, I.; Rastrelli, L.; Daglia, M.; Xiao, J.; et al. Flavonoid biosynthetic pathways in plants: Versatile targets for metabolic engineering. Biotechnol. Adv. 2020, $38,107316$. [CrossRef] [PubMed]

54. Langcake, P.; Pryce, R.J. The production of resveratrol and the viniferins by grapevines in response to ultraviolet irradiation. Phytochemistry 1977, 16, 1193-1196. [CrossRef]

55. Keylor, M.H.; Matsuura, B.S.; Stephenson, C.R.J. Chemistry and biology of resveratrol-derived natural products. Chem. Rev. 2015, 115, 8976-9027. [CrossRef]

56. Shen, T.; Wang, X.-N.; Lou, H.-X. Natural stilbenes: An overview. Nat. Prod. Rep. 2009, 26, 916-935. [CrossRef] [PubMed]

57. Xiao, K.; Zhang, H.-J.; Xuan, L.-J.; Zhang, J.; Xu, Y.-M.; Bai, D.-L. Stilbenoids: Chemistry and bioactivities. In Studies in Natural Products Chemistry; Atta-ur-Rahman, Ed.; Elsevier: Amsterdam, The Netherlands, 2008; pp. 453-646.

58. Vannozzi, A.; Dry, I.B.; Fasoli, M.; Zenoni, S.; Lucchin, M. Genome-wide analysis of the grapevine stilbene synthase multigenic family: Genomic organization and expression profiles upon biotic and abiotic stresses. BMC Plant Biol. 2012, 12, 130. [CrossRef]

59. Jeandet, P.; Clément, C.; Cordelier, S. Regulation of resveratrol biosynthesis in grapevine: New approaches for disease resistance? J. Exp. Bot. 2019, 70, 375-378. [CrossRef]

60. Vannozzi, A.; Wong, D.C.J.; Höll, J.; Hmmam, I.; Matus, J.T.; Bogs, J.; Ziegler, T.; Dry, I.; Barcaccia, G.; Lucchin, M. Combinatorial regulation of stilbene synthase genes by wrky and myb transcription factors in grapevine (Vitis vinifera L.). Plant Cell Physiol. 2018, 59, 1043-1059. [CrossRef]

61. Höll, J.; Vannozzi, A.; Czemmel, S.; D’Onofrio, C.; Walker, A.R.; Rausch, T.; Lucchin, M.; Boss, P.K.; Dry, I.B.; Bogs, J. The R2R3-MYB transcription factors MYB14 and MYB15 regulate stilbene biosynthesis in Vitis vinifera. Plant Cell 2013, 25, 4135-4149. [CrossRef] 
62. Rimando, A.M.; Pan, Z.; Polashock, J.J.; Dayan, F.E.; Mizuno, C.S.; Snook, M.E.; Liu, C.-J.; Baerson, S.R. In planta production of the highly potent resveratrol analogue pterostilbene via stilbene synthase and O-methyltransferase co-expression. Plant Biotechnol. J. 2012, 10, 269-283. [CrossRef]

63. Hall, D.; De Luca, V. Mesocarp localization of a bi-functional resveratrol/hydroxycinnamic acid glucosyltransferase of Concord grape (Vitis labrusca). Plant J. 2007, 49, 579-591. [CrossRef] [PubMed]

64. Tian, B.; Liu, J. Resveratrol: A review of plant sources, synthesis, stability, modification and food application. J. Sci. Food Agric. 2020, 100, 1392-1404. [CrossRef]

65. Delaunois, B.; Cordelier, S.; Conreux, A.; Clément, C.; Jeandet, P. Molecular engineering of resveratrol in plants. Plant Biotechnol. J. 2009, 7, 2-12. [CrossRef]

66. Donnez, D.; Jeandet, P.; Clément, C.; Courot, E. Bioproduction of resveratrol and stilbene derivatives by plant cells and microorganisms. Trends Biotechnol. 2009, 27, 706-713. [CrossRef] [PubMed]

67. Fan, E.; Zhang, K.; Zhu, M.; Wang, Q. Obtaining resveratrol: From chemical synthesis to biotechnological production. Mini-Rev. Org. Chem. 2010, 7, 272-281. [CrossRef]

68. Sun, X.; Shen, X.; Jain, R.; Lin, Y.; Wang, J.; Sun, J.; Yan, Y.; Yuan, Q. Synthesis of chemicals by metabolic engineering of microbes. Chem. Soc. Rev. 2015, 44, 3760-3785. [CrossRef] [PubMed]

69. Braga, A.; Ferreira, P.; Oliveira, J.; Rocha, I.; Faria, N. Heterologous production of resveratrol in bacterial hosts: Current status and perspectives. World J. Microbiol. Biotechnol. 2018, 34, 122. [CrossRef] [PubMed]

70. Madzak, C. Yarrowia lipolytica: Recent achievements in heterologous protein expression and pathway engineering. Appl. Microbiol. Biotechnol. 2015, 99, 4559-4577. [CrossRef] [PubMed]

71. Rainha, J.; Gomes, D.; Rodrigues, L.R.; Rodrigues, J.L. Synthetic biology approaches to engineer Saccharomyces cerevisiae towards the industrial production of valuable polyphenolic compounds. Life 2020, 10, 56. [CrossRef] [PubMed]

72. Thapa, S.B.; Pandey, R.P.; Park, Y.I.; Sohng, J.K. Biotechnological advances in resveratrol production and its chemical diversity. Molecules 2019, 24, 2571. [CrossRef] [PubMed]

73. Wang, J.; Yang, Y.; Yan, Y. Bioproduction of Resveratrol. In Biotechnology of Natural Products; Schwab, W., Lange, B.M., Wüst, M., Eds.; Springer International Publishing: Cham, Switzerland, 2018; pp. 61-79.

74. Groenewald, M.; Boekhout, T.; Neuvéglise, C.; Gaillardin, C.; Van Dijck, P.W.; Wyss, M. Yarrowia lipolytica: Safety assessment of an oleaginous yeast with a great industrial potential. Crit. Rev. Microbiol. 2014, 40, 187-206. [CrossRef]

75. Beopoulos, A.; Chardot, T.; Nicaud, J.-M. Yarrowia lipolytica: A model and a tool to understand the mechanisms implicated in lipid accumulation. Biochimie 2009, 91, 692-696. [CrossRef] [PubMed]

76. Madzak, C. Engineering Yarrowia lipolytica for use in biotechnological applications: A review of major achievements and recent innovations. Mol. Biotechnol. 2018, 60, 621-635. [CrossRef]

77. Becker, J.V.; Armstrong, G.O.; Van Der Merwe, M.J.; Lambrechts, M.G.; Vivier, M.A.; Pretorius, I.S. Metabolic engineering of Saccharomyces cerevisiae for the synthesis of the wine-related antioxidant resveratrol. FEMS Yeast Res. 2003, 4, 79-85. [CrossRef]

78. Beekwilder, J.; Wolswinkel, R.; Jonker, H.; Hall, R.; de Vos, C.H.R.; Bovy, A. Production of resveratrol in recombinant microorganisms. Appl. Environ. Microbiol. 2006, 72, 5670-5672. [CrossRef]

79. Zhang, Y.; Li, S.-Z.; Li, J.; Pan, X.; Cahoon, R.E.; Jaworski, J.G.; Wang, X.; Jez, J.M.; Chen, F.; Yu, O. Using unnatural protein fusions to engineer resveratrol biosynthesis in yeast and mammalian cells. J. Am. Chem. Soc. 2006, 128, 13030-13031. [CrossRef]

80. Trantas, E.; Panopoulos, N.; Ververidis, F. Metabolic engineering of the complete pathway leading to heterologous biosynthesis of various flavonoids and stilbenoids in Saccharomyces cerevisiae. Metab. Eng. 2009, 11, 355-366. [CrossRef] [PubMed]

81. Sydor, T.; Schaffer, S.; Boles, E. Considerable increase in resveratrol production by recombinant industrial yeast strains with use of rich medium. Appl. Environ. Microbiol. 2010, 76, 3361-3363. [CrossRef]

82. Shin, S.-Y.; Han, N.S.; Park, Y.-C.; Kim, M.-D.; Seo, J.-H. Production of resveratrol from p-coumaric acid in recombinant Saccharomyces cerevisiae expressing 4-coumarate: Coenzyme A ligase and stilbene synthase genes. Enzym. Microb. Technol. 2011, 48, 48-53. [CrossRef]

83. Wang, Y.; Halls, C.; Zhang, J.; Matsuno, M.; Zhang, Y.; Yu, O. Stepwise increase of resveratrol biosynthesis in yeast Saccharomyces cerevisiae by metabolic engineering. Metab. Eng. 2011, 13, 455-463. [CrossRef] [PubMed]

84. Shin, S.-Y.; Jung, S.-M.; Kim, M.-D.; Han, N.S.; Seo, J.-H. Production of resveratrol from tyrosine in metabolically engineered Saccharomyces cerevisiae. Enzym. Microb. Technol. 2012, 51, 211-216. [CrossRef]

85. Wang, Y.; Yu, O. Synthetic scaffolds increased resveratrol biosynthesis in engineered yeast cells. J. Biotechnol. 2012, 157, 258-260. [CrossRef]

86. Wang, Y.; Chen, H.; Yu, O. A plant malonyl-CoA synthetase enhances lipid content and polyketide yield in yeast cells. Appl. Microbiol. Biotechnol. 2014, 98, 5435-5447. [CrossRef]

87. Sun, P.; Liang, J.-L.; Kang, L.-Z.; Huang, X.-Y.; Huang, J.-J.; Ye, Z.-W.; Guo, L.-Q.; Lin, J.-F. Increased resveratrol production in wines using engineered wine strains Saccharomyces cerevisiae EC1118 and relaxed antibiotic or auxotrophic selection. Biotechnol. Prog. 2015, 31, 650-655. [CrossRef]

88. Li, M.; Kildegaard, K.R.; Chen, Y.; Rodriguez, A.; Borodina, I.; Nielsen, J. De novo production of resveratrol from glucose or ethanol by engineered Saccharomyces cerevisiae. Metab. Eng. 2015, 32, 1-11. [CrossRef]

89. Li, M.; Schneider, K.; Kristensen, M.; Borodina, I.; Nielsen, J. Engineering yeast for high-level production of stilbenoid antioxidants. Sci. Rep. 2016, 6, 36827. [CrossRef] [PubMed] 
90. Villa-Ruano, N.; Rivera, A.; Rubio-Rosas, E.; Landeta-Cortés, G.; Varela-Caselis, J.L.; Romero-Arenas, O. Comparative activity of six recombinant stilbene synthases in yeast for resveratrol production. Appl. Sci. 2020, 10, 4847. [CrossRef]

91. Yuan, S.-F.; Yi, X.; Johnston, T.G.; Alper, H.S. De novo resveratrol production through modular engineering of an Escherichia coli-Saccharomyces cerevisiae co-culture. Microb. Cell Factories 2020, 19, 143. [CrossRef] [PubMed]

92. Huang, L.L.; Xue, Z.; Zhu, Q.Q. Method for the Production of Resveratrol in a Recombinant Oleaginous Microorganism. U.S. Patent USOO7772444B2, 10 August 2010.

93. Palmer, C.M.; Miller, K.K.; Nguyen, A.; Alper, H.S. Engineering 4-coumaroyl-CoA derived polyketide production in Yarrowia lipolytica through a $\beta$-oxidation mediated strategy. Metab. Eng. 2020, 57, 174-181. [CrossRef]

94. He, Q.; Szczepańska, P.; Yuzbashev, T.; Lazar, Z.; Ledesma-Amaro, R. De novo production of resveratrol from glycerol by engineering different metabolic pathways in Yarrowia lipolytica. Metab. Eng. Commun. 2020, 11, e00146. [CrossRef] [PubMed]

95. Gu, Y.; Ma, J.; Zhu, Y.; Ding, X.; Xu, P. Engineering Yarrowia lipolytica as a chassis for de novo synthesis of five aromatic-derived natural products and chemicals. ACS Synth. Biol. 2020, 9, 2096-2106. [CrossRef] [PubMed]

96. Sáez-Sáez, J.; Wang, G.; Marella, E.R.; Sudarsan, S.; Cernuda Pastor, M.; Borodina, I. Engineering the oleaginous yeast Yarrowia lipolytica for high-level resveratrol production. Metab. Eng. 2020, 62, 51-61. [CrossRef]

97. Wang, L.; Deng, A.; Zhang, Y.; Liu, S.; Liang, Y.; Bai, H.; Cui, D.; Qiu, Q.; Shang, X.; Yang, Z.; et al. Efficient CRISPR-Cas9 mediated multiplex genome editing in yeasts. Biotechnol. Biofuels 2018, 11, 277. [CrossRef]

98. Chen, R.; Yang, S.; Zhang, L.; Zhou, Y.J. Advanced strategies for production of natural products in yeast. iScience 2020, 23,100879 [CrossRef] [PubMed]

99. Jiang, H.; Wood, K.V.; Morgan, J.A. Metabolic engineering of the phenylpropanoid pathway in Saccharomyces cerevisiae. Appl. Environ. Microbiol. 2005, 71, 2962-2969. [CrossRef] [PubMed]

100. Rodriguez, A.; Kildegaard, K.R.; Li, M.; Borodina, I.; Nielsen, J. Establishment of a yeast platform strain for production of p-coumaric acid through metabolic engineering of aromatic amino acid biosynthesis. Metab. Eng. 2015, 31, 181-188. [CrossRef]

101. Shrestha, A.; Pandey, R.P.; Sohng, J.K. Biosynthesis of resveratrol and piceatannol in engineered microbial strains: Achievements and perspectives. Appl. Microbiol. Biotechnol. 2019, 103, 2959-2972. [CrossRef] [PubMed]

102. Yang, Y.; Lin, Y.; Li, L.; Linhardt, R.J.; Yan, Y. Regulating malonyl-CoA metabolism via synthetic antisense RNAs for enhanced biosynthesis of natural products. Metab. Eng. 2015, 29, 217-226. [CrossRef] [PubMed]

103. Lu, Y.; Shao, D.; Shi, J.; Huang, Q.; Yang, H.; Jin, M. Strategies for enhancing resveratrol production and the expression of pathway enzymes. Appl. Microbiol. Biotechnol. 2016, 100, 7407-7421. [CrossRef]

104. Lim, C.G.; Fowler, Z.L.; Hueller, T.; Schaffer, S.; Koffas, M.A. High-yield resveratrol production in engineered Escherichia coli. Appl. Environ. Microbiol. 2011, 77, 3451-3460. [CrossRef]

105. Wu, J.; Yu, O.; Du, G.; Zhou, J.; Chen, J. Fine-tuning of the fatty acid pathway by synthetic antisense RNA for enhanced (2S)-naringenin production from L-tyrosine in Escherichia coli. Appl. Environ. Microbiol. 2014, 80, 7283-7292. [CrossRef] [PubMed]

106. Liang, J.-1.; Guo, L.-q.; Lin, J.-f.; He, Z.-q.; Cai, F.-j.; Chen, J.-f. A novel process for obtaining pinosylvin using combinatorial bioengineering in Escherichia coli. World J. Microbiol. Biotechnol. 2016, 32, 102. [CrossRef] [PubMed]

107. Wu, J.; Du, G.; Chen, J.; Zhou, J. Enhancing flavonoid production by systematically tuning the central metabolic pathways based on a CRISPR interference system in Escherichia coli. Sci. Rep. 2015, 5, 1-14. [CrossRef] [PubMed]

108. Na, D.; Yoo, S.M.; Chung, H.; Park, H.; Park, J.H.; Lee, S.Y. Metabolic engineering of Escherichia coli using synthetic small regulatory RNAs. Nat. Biotechnol. 2013, 31, 170-174. [CrossRef]

109. Zha, W.; Rubin-Pitel, S.B.; Shao, Z.; Zhao, H. Improving cellular malonyl-CoA level in Escherichia coli via metabolic engineering. Metab. Eng. 2009, 11, 192-198. [CrossRef]

110. Lütke-Eversloh, T.; Stephanopoulos, G. L-tyrosine production by deregulated strains of Escherichia coli. Appl. Microbiol. Biotechnol. 2007, 75, 103-110. [CrossRef] [PubMed]

111. Bulter, T.; Bernstein, J.R.; Liao, J.C. A perspective of metabolic engineering strategies: Moving up the systems hierarchy. Biotechnol. Bioeng. 2003, 84, 815-821. [CrossRef] [PubMed] 